\title{
PREVENTING CAPITAL MARKET VIOLATIONS AND CRIMES IN THE CONTEXT OF THE SELF-REGULATORY ORGANIZATION FUNCTION*
}

\author{
Sulistiowati** $^{* *}$ and Paripurna ${ }^{* * *}$ \\ Department of Business Law, Faculty of Law Universitas Gadjah Mada, Yogyakarta \\ Jalan Sosio Yustisia No. 1 Bulaksumur, Sleman, D.I. Yogyakarta 55281
}

\begin{abstract}
This study examines the preventive measures that can be taken by the Indonesian Stock Exchange (IDX) in their capacity as an SRO in response to capital market infractions. The main role of IDX is as a provider of facilities and infrastructure in capital market activities. Nonetheless, as a self-regulatory organization (SRO) IDX has additional role as regulator of the capital markets with limited authority. This study found that IDX was quite consistent in upholding the legislation in the field of capital markets. However, compliance level of the exchange members is still quite low.
\end{abstract}

Keywords: SRO, IDX, capital market, compliance.

\section{Intisari}

Penelitian ini meneliti langkah-langkah pencegahan pelanggaran dan kejahatan pasar modal yang dapat diambil oleh BEI dalam kapasitasnya sebagai SRO. Peran utama BEI adalah sebagai penyedia sarana dan prasarana dalam kegiatan kepasarmodalan. Meskipun demikian, sebagai self-regulatory organization (SRO) BEI mempunyai peran tambahan sebagai regulator pasar modal dengan kewenangan terbatas dalam menetapkan peraturan. Penelitian ini menemukan bahwa BEI telah cukup konsisten dalam menegakkan peraturan perundang-undangan di bidang pasar modal. Akan tetapi tingkat kepatuhan anggota bursa dapat dikatakan masih cukup rendah.

Kata Kunci: SRO, BEI, pasar modal, kepatuhan.

\section{Pokok Muatan}

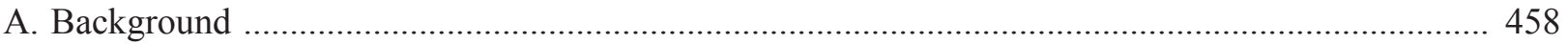

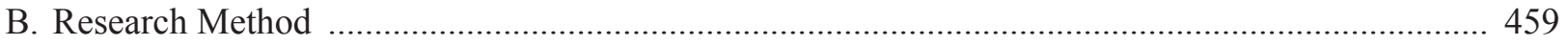

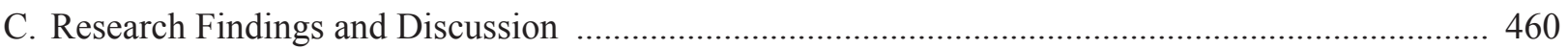

1. Primer on the Form of Self-Regulatory Organization and Their Impact on the Effort to Prevent Capital Market Violations and Crimes …………….......................................................... 460

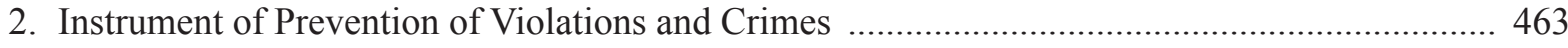

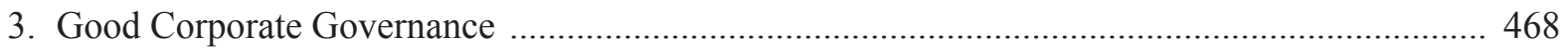

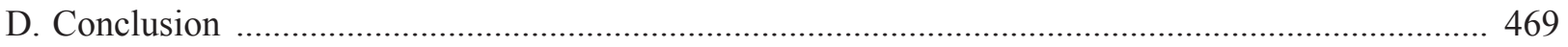

" Report of Research, funded by the Daftar Isian Pelaksanaan Anggaran (DIPA) UGM in 2013-2014.

** E-mail correspondence: sulistyowati.fhugm@gmail.com

**** E-mail correspondence: paripurna@gmail.com 


\section{A. Background}

In exercising its function as the administrator of the Indonesian capital market, the main role of the Indonesian Stock Exchange (IDX) is as a facilitator or provider of facilities and infrastructure (Article 7 paragraph (1) of UUPM ${ }^{1}$ ). Even so, as a self-regulatory organization (SRO), IDX plays an additional role as the regulator of the capital market with a limited authority in promulgating regulations. The legal basis for this role is Article 9 paragraph 1 of UUPM. Presently, the role of the regulator is in support of IDX's role as facilitator; in fulfilling its role as facilitator, IDX requires the authority of promulgating rules to organize systems and facilities for the purposes of organizing trade that is orderly, fair and efficient.

The concept of a self-regulatory organization may prove useful to complete the role of the regulator in achieving the aims of capital market regulation, ${ }^{2}$ encouraging the creation of a more efficient trading market, and further increase public access to the capital market, which in turn will improve the economy. ${ }^{3}$ The rationale behind the self-regulatory authority is in reality simple: the regulatory body would be better equipped to create effective and useful capital market regulations if it has comprehensive and real-time knowledge on capital market activities taking place on the trading floor. A regulator whose daily activity centers on the market has an attachment with the capital market system as to enable them to promulgate regulations which are accountable and compatible with market needs. In short, the self-regulation concept is supported by the idea that an efficient regulatory setting can be attained by creating a combination of the knowledge of a trader which the securities exchange has, with the supervisory capabilities of the government (in Indonesia: Bapepam-LK, now OJK). ${ }^{4}$ Furthermore, the factor of proximity also eliminates the "us versus them" mentality which may hamper synergy. ${ }^{5}$ As the ones creating the rules of securities exchange are also those who organize stock exchange activities, the SRO concept eliminates sectoral sentiments which potentially create regulatory delays.

From the aforementioned description, it is clear that the concept of self-regulation rests upon the unique symbiotic mutualism relationship between private needs and public needs, which is driven by the desire to attain an efficient regulatory regime. ${ }^{6}$ This symbiosis is realized through healthy and efficient regulation for the complex, dynamic and ever-changing capital market industry.

However, on the other hand, lays a weakness inherent in SROs. Several scholars employ the analogy of a fox guiding the chicken coop $^{7}$ namely that this concept is an oxymoron, ${ }^{8}$ with the fundamental weakness of conflict of interests. An SRO plays the dual-role as the organizer of capital market and as its regulator. This dual nature gives

Law Number 8 of 1995 on Capital Market (State Gazette of the Republic of Indonesia Number 64 of 1995, Supplement to State Gazette of the Republic of Indonesia Number 3608).

IOSCO Public Document No. 110, Model for Effective Self-Regulation, IOSCO SRO Consultative Committee (Mei 2000$)$, p. 1.

According to IOSCO, self-regulation is an important part in the framework of ca pital market regulation. Its importance is such that the implementation of SROs is made as recommendation to countries developing their capital markets. This concept is used as a sort of strategy aiming to improve regulatory effectiveness and capital market integrity. IOSCO states that the concept of SROs is useful in improving the capacity to regulate and encourage compliance of securities exchange members with existing regulations.

John Carson, 2011, Self-Regulation in Securities Markets, Policy Research Working Paper, Securities Market Group Global Capital Market Department Financial and Private Sector Development Vice Presidency, World Bank, New York, p. 54.

Michael Deshmukh, "Is FINRA a State Actor? A Question that Exposes the Flaws of the State Action Doctrine and Suggests a Way to Redeem It", Vanderbilt Law Review, Vol. 67, No. 4, April 2014, p. 1189.

See the testimony of John A. Thain (CEO, NYSE Group, Inc.) before the US Senate: A Review of Self-Regulatory Organizations in the Securities Markets: Hearing before the S. Comm. on Banking, Hous., \& Urban Affairs., 109th Cong., 2nd Sess. $9^{\text {th }}$ March 2006 , p. 5.

In several States, the formation of SROs is further driven by limitations of the resources of government authority. In the United States of America, for example, self-regulation is viewed as the proper solution to the issue of regulator's expertise, the issue of conflicting interest between the regulator and capital market organizer, the issue of limitation of the government authority (in this sense, the Securities and Exchange Commission), and the issue of complexity of business transactions which would be difficult to regulate in detail by the law.

See for example, Cary Coglianese et al., 2004, The Role of Government in Corporate Governance, Regulatory Policy Program Report RPP08, Harvard University, Cambridge, p. 5.

Steven Irwin et al., "Self-Regulation of the American Retail Securities Market - An Oxymoron for What is Best for Investors?", University of Pennsylvania Journal of Business Law, Vol. 14, No. 4, 2014, p. 1055. 
rise to the potential for conflict of interests, as a securities exchange has two polarized functions: the function of serving the needs of its members as well as users of the securities exchange, and the function of supervising activities on the trading floor. ${ }^{9}$ Several steps have been taken in order to prevent the manifestation of this potential for conflict of interests. One of the most important measures is the establishment of the authority of Bapepam-LK (now OJK) to inspect and approve of the suggestion of regulations from IDX. This provision does invade upon the authority of IDX, but it is highly important in order to ensure the conceptual integrity of an SRO.

In the context of its authority as organizers and regulators of the securities exchange, IDX holds a unique position in meeting its statutory aims of organizing a trading market for securities that is orderly, fair and efficient. The IDX is demanded to accommodate two interests which often contradict: the needs of a member of a securities exchange to increase trading volumes and the public interest of preserving the orderliness of stock exchange. Hence, the structure of an SRO must be maintained to an extent as to prevent conflicts of interests, so that the function of the regulator is not burdened or influenced by pressures of business interests.

From the following background, it would be interesting to examine how IDX's performance as an SRO in preventing capital market violations and crimes in order to create an orderly, fair and efficient capital market? Several important points discussed in this paper are inter alia the dual-role of IDX as the organizer and regulator of the capital market pursuant to UUPM and other regulations on capital market as well as the implementation of preventive and inspecting instruments applied by IDX.

\section{B. Research Method}

This research employs a judicial normative and empirical method. As a judicial normative reseach, the reseacher conducted desk studies to examine the judicial basis for regulations on the role of IDX as an SRO in the capital market. This research is also empirical in nature, being based on primary and secondary data. Primary data was obtained through focus group discussions and continued with in depth interviews with stakeholders in the field of Indonesian capital market, namely PT $\mathrm{BEI}, \mathrm{OJK}$ and issuers, as well as contributions from assisting researchers. Secondary data was obtained from PT BEI and OJK. Furthermore, the form of contribution of assisting researchers from PT BEI is made in the form of inputs and analysis, as well as support in the form of relevant data in answering the issues raised in this research.

The data required in the formulation of this research are inter alia:

1) The form, type and incidents of capital market violations and crimes;

2) Regulations issued by IDX to exercise its legal function in affording protection to investors, law enforcement and preventing capital market violations and crimes; and

3) The form of law enforcement against capital market violations and crimes in Indonesia.

In accordance with the spescific aim of the research, the location for this research is PT Bursa Saham Indonesia (Indonesian Stock Exchange) as an organizer which also implements a limited regulatory authority in the field of capital market. The research and data collection were conducted through focus group discussion (FGD) involving OJK as a regulator in the field of capital market in Indonesia. 


\section{Image 2. The Research Process Prepared by Researchers}

\begin{tabular}{|c|c|}
\hline $\begin{array}{c}\text { Define } \\
\text { Reaserch Objective }\end{array}$ & $\begin{array}{l}\text { 1. Role of IDX as SRO in the enforcement of Capital Market Law in } \\
\text { Indonesia for the sake of legal certainly in protecting the investors } \\
\text { interests and other stakeholders in the market. } \\
\text { 2. Strengthening the organization capacity of IDX as SRO in preventing } \\
\text { violation and crime in order to create an orderly, fair, and efficient } \\
\text { capital market. }\end{array}$ \\
\hline Input Phase & $\begin{array}{l}\text { a. Literature study as well as laws and regulations regarding the law } \\
\text { enforcement practice in the field of capital market in Indonesia. } \\
\text { b. Identifying cases on the violation and crime against capital market, } \\
\text { Securities Exchange Regulation \& law enforcement on such violation and } \\
\text { crime against capital market in Indonesia. }\end{array}$ \\
\hline Process Phase & $\begin{array}{l}\text { a. Collecting secondary data in Securities Exchange and OJK. } \\
\text { b. Conducting Focus Group Discussion and In-deph interview. } \\
\text { c. Analysis and Synthesis of research result. }\end{array}$ \\
\hline Output Phase & $\begin{array}{l}\text { Recommendation toward strengthening the organizational of IDX } \\
\text { as SRO in creating a orderly, fair, and efficient capital market. }\end{array}$ \\
\hline
\end{tabular}

\section{Research Result and Discussion}

1. Primer on the Form of Self-Regulatory Organization and Their Impact on the Effort to Prevent Capital Market Violations and Crimes

The discussion of the capability of the capital market to prevent violations and crimes in the field of capital market would not be complete without the discussion of the conflict of interest created as a result of the SRO form. A stock exchange would not be able to operate without investor trust. Investors are inclined to only be willing to trade in a securities exchange that they have trust is (for example, due to reasons of security, personal preference over the companies listed on the exchange, or a more lax rules of conduct compared to other stock exchanges). The same also applies to the securities exchange members. As a result, a stock exchange which fails to accommodate the needs of the investing public and the needs of its members will slowly be abandoned. This shows that securities exchanges more or less depend upon the obligation to ensure that both its members and investors are constantly content.

However, on the other hand, this obligation of investor protection calls into question the ability of the securities exchange in ensuring that trading activities on the trading floor are conducted transparently, efficiently and in an orderly manner. Would the securities exchange still be able to issue securities exchange regulations which are fair and not partial to investors (reflect favouritism)? In other words, a securities exchange must conduct measures to prevent violations and crimes in the field of capital market without being adversely affected by its close relationship with the investing public and securities exchange members. Only with this policy of impartiality of securities exchange can we hope to attain a capital market that is orderly, fair and efficient consistent with the mandate of the UUPM.

\section{a. The Advantages and Disadvantages of Self-regulation}

The research results show that selfregulation has proven to be an efficient means of regulation. The flexible nature of SROs enable them to adapt to rapidly changing business environments. Self-regulation is further proven to be an efficient means of regulation. The regulations are formulized by the market makers having intensive knowledge on the market, who know how to maximize the benefits of the regulations (inter alia, an orderly market, consumer protection, the reduction of systemic risks) and minimizing business expenses. An in-depth 
knowledge on the market is highly important to create a self-regulatory framework which would be perceived as appropriate and fair by the individuals regulated and entities. This perception will in turn effectuate a high degree of compliance by market makers operating the self-regulatory framework.

Although having great benefits, self-regulation also comes with several disadvantages, which are inter alia selfinterest, poor adequate law enforcement, the tendency to monopolize and favoritism. ${ }^{10}$ These weaknesses commonly stem from doubts as to how an SRO can protect the public interest without resulting in financial losses. Self-regulation even creates the concern that it could grant benefits for uncompetitive market makers. Through the SRO mechanism, its members and every involved SRO would be enabled to create an understanding to regulate and to implement certain behaviors and business patterns. In an industry, all other factors notwithstanding, if another member as well as competitor holds the same power to approve and enact such an understanding, no competition will further be had.

Another issue raised by self-regulation is favoritism. Self-regulation is implemented by SROs, who are very likely to be dominated by major or stable companies. The regulatory policies created could be beneficial to their interests only, rather than that of other members or that of the public interest. ${ }^{11}$

The aforementioned advantages and disadvantages of the SRO concept can be described using the following matrix: ${ }^{12}$

Table 1. Advantages and Disadvantages of the SRO Concept

\begin{tabular}{l} 
Advantage \\
\hline Proximity. SROs have the advantage of proximity \\
with the supervised activity. SROs tend to receive \\
up-to-date information faster, which enable it to \\
immediately respond to important recent events. \\
Furthermore, SROs have more capital market \\
experts than the government.
\end{tabular}

Flexibility. As the SRO is not a governmental institution, SROs tend to be free from political influence and the obligation to adhere to procedures which tend to be rigid.

Compliance. Their involvement in promulgating
regulations can be a persuasive element for market
makers to adhere to the regulations of the securities
exchange. Additionally, there is the perspective that
creating SROs can resolve issues in the securities
exchange in an elegant manner and in a manner
consistent with the interests of the market makers.

Common interest. Self-regulation can be seen as an opportunity to create a participatory compliance climate, where market makers can supervise one another.

\section{Disadvantage}

Conflict of Interests. Even though SROs have more experts than the government, this does not necessarily mean that SROs will not prioritize its own interest over that of the public, which may alter the aim of a regulatory setting to that of a private aim instead of public.

Half-Hearted Sanctions. Given its flexible governance model, there is the possibility that SROs may only issue light sanctions for severe violations.

Poor Law Enforcement. When the capital market industry is at odds with public interests, SROs may be tempted to not enforce the law optimally. 
Self-funding. As the funding of SROs originates from within themselves, SROs are immune from the effects of money politics and from the treat of external financing cuts.
Financing Limitation. Being self-funding, SROs are susceptible to financing shortfalls and difficulties in obtaining additional funds due to conflict of interests.

\section{b. The Process of Creating Securities Exchange Regulations and OJK Approval}

The internal regulations of IDX prescribe the dissemination of a drafted regulation throughout the creation process. Public testing must be conducted to gauge the reaction of market makers prior to the regulations' ratification. The involvement of stockholders by IDX in this process usually last for a duration of two weeks. In this process, the IDX not only provides hardcopies but also softcopies of the regulation. The stockholders are invited and given an explanation on the intention of PT $\mathrm{BEI}$ to issue a new regulation as well as the scope of matters covered. During this phase the stockholders can directly give feedback on the drafted regulation.

The involvement of stockholders from the earliest stage of rule-making should render the stockholders compliant to such rules. There should be no reason for non-compliance, bearing in mind that the stockholders are enabled to participate in the determination of regulations, and that they have agreed to the new regulation. ${ }^{13}$ After this process is completed, PT BEI requires the approval of OJK in ratifying the regulation. The approval of OJK is a mandatory requirement in the process of making rules. ${ }^{14}$ If the approval of the OJK is not obtained, then the regulation may not be enacted. ${ }^{15}$

The approval of OJK is a crucial component in ensuring the conceptual integrity of an SRO, as OJK's approval acts as a check point to assist in supervising the conduct ot the SRO. ${ }^{16}$ Through the approval of OJK, the effects of conflicts of interest can be reduced. However, it must nonetheless be born in mind that one of the greatest challenges faced by the government in planning and managing the framework of law supervision is to exercise the proper degree of governmental supervision of SRO activities without reducing the ability of the SRO to respond in a quick manner and to be flexible in facing changes in market conditions and business needs.

The issue of delay in approving the drafts of securities exchange regulations has become a serious problem in the United States of America. ${ }^{17}$ Regulations issued by SROs (for example NYSE and NASDAQ) need to obtain the approval of the Securities and Exchange Commission (SEC) prior to being implementable. However, this policy of layered approval is not favored by several SROs given the lengthy time required by the SEC in evaluating the SRO regulation drafts. Given the high intensity of the competition climate in the US, this SEC delay reflects negatively upon the competitiveness of the securities exchange.

Focus Group Discussion II (FGD II), Nindyo Pramono, Professor of the Faculty of Law, UGM, on $15^{\text {th }}$ November 2013.

4 See Bapepam Regulation III.A.2. jo. the Decision of the Head of Badan Pengawas Pasar Modal Number Kep-03/PM/1996 on the Procedure of Promulgating Regulations by the Securities Exchange.

15 Focus Group Discussion I (FGD I), Dewi Arum Prasetyaningtyas, Head of the Legal Division of PT BEI, on $23^{\text {rd }}$ Augusts 2013.

16 The importance of governmental authority as a form of SRO supervision is further affirmed in the United States of America: "The Commission's oversight function has two aspects: [...] and a negative responsibility of assuring that delegated power is not exercised in a manner inimical to the public interest or unfair to private interests". Report of the US Senate No. 75 (94 ${ }^{\text {th }}$ Cong., 1st Sess., 1975$)$, p. 34.

17 Jonathan G. Katz, 2009, Examining the Efficiency and Effectiveness of the U.S. Securities and Exchange Commission, U.S. Chamber of Commerce, Washington D.C., p. 41. 
Although Indonesia only has one securities exchange dominating the market, the issue of competitiveness is nonetheless a valid point to question. Is the deadline of 60 days to approve/reject the securities exchange regulation too long as to reduce the competitiveness of the Indonesian Stock Exchange?

The sources mentioned that in its practical manner, the application of Rule III.A. 2 does not have a particular standard on how long it takes for a securities exchange regulation to finally take place. Most of the securities exchange regulations proposed to OJK would highly likely be approved. In the case that such regulation is not approved, OJK will return it to the Securities Exchange for a revision which finally will also be approved by OJK.

Reviews made in 2007 (JulySeptember) do not indicate evaluations made on the duration required by OJK (formerly Bapepam) in examining the regulation draft proposed by PT BEI. ${ }^{18}$ The principles employed as the framework of capital market regulation aims to protect investors, ensure fairness, efficiency and market transparency, as well as reduce systemic risk.

\section{Instrument of Prevention of Violations and Crimes}

A model of instruments to prevent violations and crimes cannot be dismissive of the potential for conflict of interests. The following analysis of research results seeks to lay out the discussion of instruments of the prevention of violations and crimes in the context of conflicts of interest created as a direct result of the self-regulation concept.

Securities exchanges cannot operate without investor trusts. Investors tend to only be willing to conduct trade in securities exchanges that they have faith in. A securities exchange that is unable to protect the interest of the investor will slowly be abandoned. Hence, securities exchanges must ensure that trading activities on the trading floor proceed in a transparent, efficient and orderly manner, as well as a manner which ensures legal certainty. In other terms, securities exchanges must conduct measures to prevent capital market infractions which are further expected to create a capital market that is orderly, fair and efficient. The prevention of infractions can be conducted through preventive instruments targeting Issuers and Members of the securities exchange

a) Preventive Instruments Targeting Issuers

Unusual Market Activity (UMA) refers to trading activities and/or change of price for Securities which are irregular in a defined time period in the securities exchange, which may potentially disrupt the establishment of Securities trade that is orderly, fair and efficient according to the securities exchange. The announcement of an UMA does not immediately show that there are violations of capital market laws and regulations. If a Securities is classified as an UMA, the investor is expected to take into account ${ }^{19}$ the answer of the listed company to the request for securities exchange confirmation; to scrutinize the performance of the listed company and the transparency of its information; reassess the corporate action plan of the listed company if the plan has yet received an approval from the GMS; and consider numerous possibilities which may arise in the future prior to deciding to invest.

UMAs begun to be implemented in 2008. Prior to 2008, IDX did not issue UMAs, but Letters of Investor Caution. This letter of caution holds the same function as the UMA. UMA is directed more to the investors than the issuers and is expected to provide an 
early warning for investor to exercise greater caution. The occurrence of a UMA can be caused by numerous parties, namely by the members of the securities exchange, issuers, or the investors themselves. ${ }^{20}$

Following the enactment of UMAs, the securities exchange will issue a confirmation request to the issuer to discover the reason behind the price volatility. A caveat is that this request for confirmation is not always published by the securities exchange. This further explains the reason why, in 2009, information on UMAs were not published in annual reports. ${ }^{21}$

Up until 2012 PT BEI has issued UMAs at least 317 times. These measures were enacted against at least 279 listed securities. In the event of a UMA and it is suspected that there are irregularities, the stock market authorities are entitled to suspend the securities. This suspension is not a penalty, but rather is a means to enable investors to cool down by giving them more time to gather information before making a decision to invest. Suspensions, as defined here, must not necessarily be implemented by the securities exchange. If the volatility of the securities price is due to an improved performance of the issuer which resulted in a greater surge of buying and selling, suspension would not be necessary.

Up until 2012, IDX has suspended securities at least 267 times. Suspensions were most often conducted in 2007, namely a total of 97 times. This suspension is enacted against at least 210 securities listed in the securities exchange. In the year 2007 IDX conducted 97 suspensions against 72 securities. For the following years, the number of suspensions averages to 30 suspensions per year. The following is a recapitulation of the UMA issued by IDX since 2008 .

Table 2. Supervision and Imposition of Unusual Market Transaction (UMA)

Note: (-) refers to an absence of data in the IDX Yearly Report

\begin{tabular}{cccccccc}
\hline Year & $\begin{array}{c}\text { Confirmation } \\
\text { request }\end{array}$ & UMA & on & Suspension & on & Examination & $\begin{array}{c}\text { Forwarded to } \\
\text { Bapepam }\end{array}$ \\
\hline 2007 & 116 times & - & - & 97 times & 72 Securities & 56 incidents & - \\
2008 & 211 times & 65 times & 60 Securities & 40 times & 39 Securities & 33 incidents & - \\
2009 & - & - & - & - & - & - & - \\
2010 & - & 98 times & 86 Securities & 43 times & 33 Securities & 48 incidents & 13 incidents \\
2011 & - & 72 times & 62 Securities & 35 times & 34 Securities & 40 incidents & 27 incidents \\
2012 & - & 82 times & 71 Securities & 52 times & 32 Securities & - & - \\
\hline Total & 327 times & 317 times & 279 Securities & 267 times & 210 Securities & $\mathbf{1 1 7}$ incidents & 40 incidents \\
\hline
\end{tabular}

After enacting suspensions, the securities exchange is authorized to conduct inspections. The report of this inspection shall be recommended to the OJK where there are strong indications of violations of capital market laws and regulations. The parameter for assigning the matter to OJK is based upon findings from documents, transaction patterns and the relation between investor and issuer or securities exchange member. Aside from formulating recommendations to the OJK, the trade division may also create recommendations to the membership division to implement sanctions. ${ }^{22}$ In terms of matters being assigned to the OJK, there were 13 incidents in 2010 and 27 incidents in 2011. 
Full Disclosure another preventive instrument against issuers is the implementation of full disclosure. According to Article 1 number 25 of UUPM, the principle of full disclosure is a general guideline which requires issuers, public companies and other parties to convey to the public all Material Information pertaining to their business or securities, which may have effect upon the decision of the investor on the securities or its price, in a timely manner.

The principle of full disclosure is also regulated under Article 86 paragraph 1 of UUPM. The Article stipulates that issuers whose registration statement has become effective, is obliged to:

1) Submit periodic report to OJK or Bapepam and make public such reports; and

2) Submit reports to Bapepam/OJK and make public information regarding material events which may affect the price of securities, no later than 2 (two) working days after the event.

The provision of Article 86 paragraph 1 letter $\mathrm{b}$ of UUPM is further regulated under the Decision of the Board of Directors of PT Bursa Efek Jakarta (Jakarta Stock Exchange) Number: Kep. 306/BEJ/07/2004 on Regulation Number I E on the Obligation to Submit Information. This regulation was enacted in order to increase protection of investors through provisions which can increase the quality of information transparency of listed companies.

The full disclosure principle has several judicial characteristics, namely: $:^{23}$

1) The principle of degree of information accuracy, namely that the information provided by the Issuer must be accurate;

2) The principle of degree of information completeness, namely that Issuers must provide information as complete as possible on the condition of their company to the investor candicate who will invest in the company;

3) The principle of striking equilibrium between the negative and positive effects of the information being made public, namely that the law must seek out a point of equilibrium so as to minimize the sacrificing of the interest of the involved parties, namely by making provisions on aspects which must be made public and matters which the company may keep confidential.

Information is an important element for investors and traders as it inherently provides descriptions, annotations or illustrations both for past conditions and present. Information that is complete, relevant, accurate and timely is greatly required by investors in the capital market to be analyzed before deciding to invest.

The Issuer must provide information required by the investor and OJK. The Issuer must take heed of certain matters which will be informed to the investor, and the Issuer is prohibited from providing information which is false, half-true, incomplete, or silent on material information. Information that is complete and adequate is the foundation for the formation of a fair market price.

Bapepam Regulation X.K.1 on the Disclosure of Information which shall be Immediately Made Public prescribes that a public company or issuer must submit the existence of an information or material fact to Bapepam and public as soon as possible. The types of information which are predicted to have effect on the value of the securities are inter alia: 
1) merger, purchase of shares, acquisition, or the formation of joint venture;

2) stock split and the division of stock dividens;

3) gains from dividends of an extraordinary nature;

4) obtaining or losing important contracts;

5) meaningful new products or inventions;

6) changes in control or important changes in management;

7) announcements of repurchase or payment of debt securities;

8) the sales of additional securities to the public or in a limited manner in a material quantity;

9) the purchase, or losses in selling assests which are material in nature;

10) relatively importantemployment disputes;

11) important legal actions against the company, and/or the board of directors and the board of commissioners of the company

12) the submission of offer to purchase the securities of another company;

13) changes in the accountant auditing the company;

14) changes in trustee; and

15) changes in the company's fiscal year.

\section{b) Preventive Instruments Targeting}

\section{Securities Exchange Members}

Instruments of prevention of infractions are also implemented towards securities exchange members as well as to the issuers. Such preventive instruments take the form of audits on financial capability, compliance audits and incidental audits.

What is referred to as financial capability is the ability to adequately manage finances, as well as the fulfillment of the fit and proper criteria as prescribed under laws and regulations, fulfilling the requirement of authorized capital and paid-up capital which are implemented by the securities exchange in accordance with its provisions, and also having fulfilled financial obligations including registration fees, membership fees, compensation funds, monthly contributions, and other expenses determined by the securities exchange.

An audit on the securities exchange member can also be conducted through a reporting of the Adjusted Net Working Capital (ANWC). ANWC is the basis for securities exchange members to conduct transactions in the securities exchange. ANWC is based upon Bapepam Regulation No. 5 D.V on the Maintenance and Reporting of Adjusted Net Working Capital (ANWC). Pursuant to the regulation, what is defined as ANWC is the number of current assets of the securities company subtracted by the whole liability of the Securities Company and ranking liabilities, added with the subordinated debt, with several other adjustments being made.

Security exchange members are obliged to report on ANWC in certain time periods. Pursuant to number 4 item $b$, Bapepam Regulation No 6.D.V, securities companies are obliged to maintain ANWC every working day and submit ANWC reports in accordance with Form Number V.D.5-1, Form Number V.D.5-2, Form Number V.D.5-3, Form Number V.D.5-4, Form Number V.D.5-5, Form Number V.D.56, Form Number V.D.5-7, Form Number V.D.5-8, Form Number V.D.5-9 and Form Number V.D.5-10.

Pursuant to the V.D.5 regulation, if there are securities exchange members who do not report and/or fail to meet the minimum ANWC value as prescribed under number 2 letter $b$ and letter $f$, the securities exchange is obliged to prohibit the securities exchange member from conducting securities exchange. Further, number 4 letter $d$ stipulates that if the securities company of the securities exchange member fail to meet the minimum 
ANWC value as prescribed under number 2 letter $b$ and letter $f$, the securities exchange must oblige the securities company of the securities exchange member to:

1) halt the opening of accounts by of new clients;

2) halt securities transaction which will cause an increase in the long position or short position in the portfolio of the securities company except in exercising or selling Pre-Emptive Rights;

3) halt securities transactions which would cause an increase in the debit balance or long position in the account of the client;

4) halt securities transactions in the account of the client and exercising or selling PreEmptive Rights if the ANWC deficit is over $20 \%$ (twenty percent) of the required ANWC value; and

5) convey plans to the securities exchange containing the schedule, method, and form of capital increase, reduction of business activities, or the halting of business activities as well as submitting a courtesy copy to OJK.

If the securities exchange member insufficiently or is late in reporting its ANWC, the securities exchange shall suspend the member. Following this, a team will be formed to examine the ANWC. The securities exchange is allowed to issue sanctions (such as in the form of suspensions) even when the inspection of the securities exchange member has not taken place. After the inspection, a revocation of the suspension may be conducted if the ANWC is positive. If there are infractions, the securities exchange member is lead back to compliance, and if necessary is given sanctions. ${ }^{24}$
Compliance audit of the securities exchange members is the third preventive instruments of capital market infractions in Indonesia. The audit covers the completeness of the regulations of the securities exchange members as prescribed by capital market regulations, the inspection of the procedure of regulation execution in the operation of the securities exchange members, and inspection on the information system of the securities exchange members used for trade in IDX. Compliance audit targeted towards securities exchange members cover numerous laws and regulations in the field of capital market.

To effectuate compliance, IDX can employ the means of supervision by inspections. This inspection is divided into two namely general and specialized inspections. This is an issue which the researcher has mentioned in the discussion of the first issue. The focus of inspections is adjusted upon the events transpiring at the moment or on a flexible basis. If errors are found, IDX will issue a warning for the securities exchange member to rectify the error. Furthermore, with respect to securities exchange members in violation of law and regulations, guidance can be given as to attain compliance on capital market rules and regulation. Here, guidance is aimed to correct the errors of securities exchange members. The form of guidance rendered can be in summoning or to be referred to the membership division for sanctioning. ${ }^{25}$

The next preventive instrument is incidental audit. The incidental audit is regulated under Regulation of Securities Exchange Number III E on the inspection of Securities Exchange members. Pursuant to the regulation, inspection refers to a series of activities in searching, gathering and

24 Focus Group Discussion II (FGD II), Kristian S. Manullang, Head of Membership Division of IDX, on $15^{\text {th }}$ November 2013.

25 Focus Group Discussion II (FGD II), Lidya, Head of the Compliance Division of IDX, on 15 $5^{\text {th }}$ November 2013. 
processing data and/or other information by the securities exchange to prove and/ or indicate the existence of an infraction of securities exchange regulation as well as capital market laws and regulations.

Incidental inspections are a form of supervision exercised by the securities exchange in organizing an orderly, fair and efficient trade in securities. This incidental inspection is conducted by the securities on, but not limited to, the following matters:

1) II.5.1. Inspection of the assets of Securities Exchange Members having been suspended;

2) II.5.2. Inspection of the existence of disputes or potential disputes between the Securities Exchange Members and the client or between Securities Exchange Members;

3) II.5.3. the result of monitoring related to the activities of the Securities Exchange Members;

4) II.5.4. Inspection of indications of transaction irregularities;

5) II.5.5. Inspection of Securities Exchange Members in failing to meet the minimum Adjusted Net Working Capital in accordance with the Bapepam Regulation and LK Number V.D.5 on the Maintenance and Reporting of Adjusted Net Working Capital;

6) II.5.6. Inspection of the the refulfillment of the Adjusted Net Working Capital;

7) II.5.7. Inspection in the event of failure of payment by the Securtities Exchange Members;

8) II.5.8. Inspections of the security of Securities account should the Securities Exchange Member intend to terminate its activity as a Securities Exchange Member.

This inspection can be conducted in the Securities Exchange or the location of the Securities Exchange Member, and is conducted by the Securities Exchange Inspector Task Force Unit (Satuan Pemeriksa
Bursa) based on a Letter of Assignment from the Securities Exchange. Pursuant to regulation III E on the Inspection of Securities Exchange Members item III number 3, the result of the incidental inspections on material issues found are to be conveyed to the OJK, Board of Commissioners and the Board of Directors of the Securities Exchange.

\section{Good Corporate Governance}

Aside from the aforementioned instruments, PT BEI must also promote good corporate governance in preventing infractions. As previously mentioned, one of the characteristics of good corporate governance is the transparency of information. The public, primarily market makers, ideally should be able to access information in a fast and precise manner. This is highly important bearing in mind that the main tool by which an investor can formulate a decision is information. If a piece of information arrives late, or is incorrect, the investor stands to incur losses. From a broader perspective, the securities exchange may lose trust investor trust.

Pursuant to the public goods theory doctrine, securities exchanges as the organizers of securities trade are private legal entities in the form of limited liability companies (PT). PT BEI operates in a sector of services owned and closely supervised by the government. This means that PT BEI falls into the category of public goods. The consequence of this finding is that the public must be able to access the securities exchange.

The government has the authority to regulate with respect to public goods. However, this function was delegated to the OJK as the primary regulator and also to IDX through statutes (attribution). Both entities consequently replaced the role of the government in regulating the capital market. IDX, as facilitator, is obliged to ensure that the securities exchange be accessible and enjoyable by all layers of the society. One form of access which must be afforded to all layers of the society is information related to capital market. Information can be disseminated to the public through various media, 
both printed and electronic.

PT BEI itself realizes the importance of information transparency by exercising good corporate governance. PT BEI has made the commitment to improve the governance and management of corporate risks in a continuous manner as to create a good capital market. In 2012, PT BEI has consistently implemented Good Corporate Governance, including Good IT Governance.

Drawing from the experience of the New York Stock Exchange and NASDAQ Stock Market, ${ }^{26}$ a vital issue is that on the independence and transparency of regulatory programs. Regulatory functions must be maintained to be separate from that of capital market organization to minimize the potential for conflict of interests. Although the function of an SRO is to reduce the gap between the regulated and the regulator (proximity aspect), the separation of the rule-making division must nonetheless be made as to avoid interference from the market.

Aside from the principle of good corporate governance, the implementation of IOSCO principles on self-regulation may also be a preventive mechanism against capital market infractions. The appropriate implementation of the IOSCO principle of SROs would provide added value.

However, if PT BEI is the sole entity implementing the principle of good corporate governance, without being followed by the securities exchange members, the concern is raised that the prevention of capital market violations and crimes will be less effective. A securities exchange member which is not transparent may potentially inflict losses upon clients or investors. Additionally, an inconsistent implementation of the good corporate governance principle by different members of the securities exchange must be made uniform through a minimum standard. Hence, a method must be devised to give incentive for members of the securities exchange to implement the good corporate governance principle to protect the interest of investors, and that of market makers as a whole. It is highly important for IDX to wield chief responsibility in supervising the compliance of securities exchange members to laws and regulations. One policy which may be considered is inter alia by obliging securities exchange members to apply a standard of good corporate governance that is at least equal to that applied by the SRO. This measure was taken by the Securities and Exchange Commission, which realized that SRO played a crucial role as a standard setter for listed companies. $^{27}$

The potential for violations or infractions may be suppressed with the existence of good corporate governance in PT BEI and the securities exchange members. In the end, the trade in securities which is orderly, fair and efficient would be realized.

\section{Conclusion}

IDX and other SROs are expected to continuously maximize their function as SROs in preventing capital market violations and crimes in the midst of the tumultuous global situation. To this end, IDX must be able to preserve a positive capital market sentiment, so that investors may feel secure in investing. A negative global sentiment would surely affect investors, and the success of IDX in capital market law enforcement could enable investors to feel secure in trading in the Indonesian capital market.

The key element in successfully regulating capital market activities are prophylactic approaches or prevention through compliance. The enforcement of regulations through sanctions tend to be more costly than preventive measures. One policy which may be considered is by obliging securities exchange members to apply a good corporate governance standard that is at least equal to that applied by the SRO to ensure the quality of

\footnotetext{
6 SEC Release (Proposed Rule), Release No. 34-50699, 17 C.F.R. pt. 240, 242, and 249 (2005).

27 Ibid., pp. 30-31.
} 
governance. It would be unfortunate if IDX, as a facilitator, properly implements good corporate governance principles but this is not followed by the securities exchange members. The implementation of good corporate governance principles must be made uniform through the creation of a minimum standard.

As an SRO, IDX has been sufficiently consistent in implementing capital market laws and regulations. An indicator of this is the practice of sanctioning securities exchange members in violation of laws and regulations in a fair and transparent manner. However, the degree of compliance of securities exchange member can be deemed to be fairly low. This is demonstrated in the behaviors of several securities exchange member who engage in repeat violations in a relatively short period of time; indicating the inexistence of a deterrence effect which may be due to the tendency of traders to always calculate the risks of doing business. Infractions leading to sanctions are perceived as a normal and fairly low cost of doing business, as to not necessitate a follow-up through internal improvements. Even so, this conclusion cannot be interpreted as an urge to implement sanctions across the board without assessing merit. Even though criminal sanctions may render traders and corporations to think twice before committing infractions, the implementation of criminal sanctions can be unsuitable and create an unfavorable investing climate as the government will be perceived to be ruling with an iron fist. The appropriate measure is by utilizing civil sanctions as the main threat, and employing criminal sanctions only in a selective manner.

\section{REFERENCES}

\section{A. Books}

Bapepam-LK, 2007, Siaran Pers Akhir Tahun 2007, Bapepam-LK, Jakarta.

Fuady, Munir, 1996, Hukum Bisnis dalam Teori dan Praktek, Citra Aditya Bakti, Bandung.

Katz, Jonathan G., 2009, Examining the Efficiency and Effectiveness of the U.S. Securities and Exchange Commission, U.S. Chamber of Commerce, Washington DC.

Van, Nguyen Tri Anh, 2004, Toward a Well Functioning Securities Market in Vietnam, Center for Asian Legal Exchange School of Law Nagoya University, Japan.

\section{B. Journals Articles}

Angela J. Campbell, "Self-Regulation and the Media", Federal Communication Law Journal, Vol. 51, 1999.

Deshmukh, Michael, "Is FINRA a State Actor? A Question that Exposes the Flaws of the State Action Doctrine and Suggests a Way to Redeem It", Vanderbilt Law Review, Vol. 67, No. 4, April 2014.
Irwin, Steven et al., "Self-Regulation of the American Retail Securities Market - An Oxymoron for What is Best for Investors?", University of Pennsylvania Journal of Business Law, Vol. 14, No. 4, 2014.

\section{Research Reports}

Carson, John, 2011, Self-Regulation in Securities Markets, Policy Research Working Paper, Securities Market Group Global Capital Market Department Financial and Private Sector Development Vice Presidency, World Bank, New York.

Coglianese, Cary et al., 2004, The Role of Government in Corporate Governance, Regulatory Policy Program Report RPP-08, Harvard University, Cambridge.

\section{Speech}

John A. Thain (CEO, NYSE Group, Inc.), "A Review of Self-Regulatory Organizations in the Securities Markets: Hearing before the S. Comm. on Banking, Hous., \& Urban 
Affairs", Speech, 109th Cong., 2nd Sess. $9^{\text {th }}$ March 2006.

\section{E. Regulations}

Law Number 8 of 1995 on Capital Market (State Gazette of the Republic of Indonesia Number 64 of 1995, Supplement to the State Gazette of the Republic of Indonesia Number 3608).

IOSCO Public Document No. 110, Model for Effective Self-Regulation, IOSCO SRO Consultative Committee, May 2000.

US Senate Report No. 75 (94th Cong., 1st Sess.,
1975).

Bapepam Regulation III.A.2. jo. the Decision of the Head of Badan Pengawas Pasar Modal Number Kep-03/PM/1996 on the Procedure of Promulgating Regulations by the Securities Exchange.

SEC Concept Release Concerning Self-Regulation, Exchange Act Release No. 34-50700, 17 C.F.R. pt. 240, $8^{\text {th }}$ March. 2005.

SEC Release (Proposed Rule), Release No. 3450699, 17 C.F.R. pt. 240, 242, and 249 (2005). 